\title{
Coming to Terms with Technoscience: The Heideggerian Way
}

\author{
Hub Zwart ${ }^{1}$ D \\ Published online: 5 August 2020 \\ (c) The Author(s) 2020
}

\begin{abstract}
Heidegger's oeuvre ( $>100$ volumes) contains a plethora of comments on contemporary science, or rather technoscience because, according to Heidegger, science is inherently technical. What insights can be derived from such comments for philosophers questioning technoscience as it is practiced today? Can Heidegger's thoughts become a source of inspiration for contemporary scholars who are confronted with automated sequencing machines, magnetic resonance imaging machines and other technoscientific contrivances? This is closely related to the question of method, I will argue. Although Heidegger himself was notoriously ambivalent when it came to method, especially in his later writings, his oeuvre nonetheless contains important hints for how a philosophical questioning of technoscience could be practiced, such as: paying attention to language (to the words that we use) or taking a step backwards (towards the moment of commencement of the type of rationality at work). For Heidegger, method means: being underway, and a philosophical method must be developed along the way. After discussing Heidegger's views on method, both in his earlier and in his later writings, three dimensions of contemporary technoscience will be addressed, namely: technoscientific objects (research artefacts), technoscientific sites (laboratories as unworldly environments) and technoscience as a global enterprise. In the final section, the question will be addressed whether and how a critical encounter between philosophy and technoscience is possible.
\end{abstract}

Keywords Heidegger $\cdot$ Technoscience $\cdot$ Philosophical method $\cdot$ Life sciences

Hub Zwart

zwart@esphil.eur.nl

https://www.eur.nl/esphil/people/hub-zwart

1 Dean Erasmus School of Philosophy, Erasmus University Rotterdam, Bayle Building, Room J5-65, Burgemeester Oudlaan 50, 3062 PA Rotterdam, The Netherlands 


\section{Introduction}

Imagine a group of philosophy students, about to complete a Master's program in continental philosophy, who are invited to visit a life sciences research laboratory, somewhere on a university campus. Having studied some of Heidegger's quintessential works, such as Being and Time and The Question of Technology, they suddenly find themselves exposed to racks of test-tubes and automated sequencing machines. Suppose that, thrown into such an "unworldly" lab environment, they ask themselves how to interpret their experiences in a Heideggerian manner.

On closer inspection, this scene is far from fictitious. Being a continental philosopher myself, having worked in a science faculty for almost two decades, I often conversed with philosophy students, versant in the oeuvres of Heidegger and other continental thinkers, who were suddenly challenged to develop a philosophical commentary on emerging trends in contemporary technoscience, be it quantum computing, neuro-imaging or CRISPR-cas9. How to bridge, in a meaningful manner, the distance that segregates the world of philosophy seminars from the world of high-tech experimental inquiry? How to convince philosophers that this is not an embarrassment which they should forego, but an opportunity for which they should prepare themselves? Philosophy, I will argue, desperately needs these exposures to the intricate realities of technoscience, while technoscientific inquiry is evidently in need of philosophical assessment, notably from a continental perspective. How to turn such mutual exposures into meaningful intellectual experiences for both sides: for technoscience as well as for Heideggerian philosophy?

Scattered across Heidegger's oeuvre, we find intriguing comments on contemporary science or technoscience because, although Heidegger himself did not use this term, he does emphasise the inherent technicity of science. For Heidegger, science (technoscience) is inherently technical, imbued with technicity, thereby precluding other (more poetic) ways of understanding nature (Glazebrook 2012). What lessons can be derived from such comments for philosophers who are on their way to questioning technoscience as it is practiced today? Can Heidegger's thoughts on science and technoscientific "things" become a source of insight and inspiration for philosophers who are confronted with automated sequencing machines, magnetic resonance imaging machines and other technoscientific contrivances?

This is closely related to the question of method, I will argue. Although Heidegger himself was notoriously ambivalent concerning method, especially in his later writings, his oeuvre nonetheless contains important hints for how a philosophical questioning of technoscience could be practiced. For Heidegger, philosophy basically means: being underway. Could a site visit to a life science laboratory be part of a meaningful philosophical journey, underway to understanding technoscience? In a recent study on Heidegger and climate change, Vincent Blok (2020) argues that the "crisis" of contemporary philosophy (e.g., its inability to significantly contribute to addressing planetary environmental challenges) stems from "a lack of interest in the question of a philosophical method" (Blok 
2020:17), and I agree with this claim. Heidegger, I will argue, provides many hints on how philosophers may learn the "handicraft" of thinking (1954/2002; GA8:18) and this paper explores how these hints (Hinweise) can help to come to terms with technoscience.

The structure of this paper is as follows. First, I will present an outline of Heidegger's views on method, both in early work and in later writings. Subsequently, I will explore Heidegger's views on technoscience, more specifically on technoscientific things (laboratory artefacts), on technoscientific sites (laboratories) and on technoscience as a global enterprise. The basic contours of a Heideggerian "method" for questioning technoscience will be fleshed out (recollected) "along the way". In the final section, the results will be assessed.

\section{Heidegger on Method: Setting the Stage}

To begin with, Heidegger thematises human existence as a lived practice and technoscience should likewise be studied as a practice. In Being and Time, Heidegger reminds us that, in ancient Greece, things were regarded as $\pi \rho \alpha ́ \gamma \mu \alpha \tau \alpha$ : entities we deal with in a practical, hands-on, caring manner (1977; GA2:92). Could this apply to entities (neo-things) we encounter in laboratories, whose way of being seems questionable from the very outset? There is something artificial and unfamiliar about laboratory artefacts. What kind of thing is a test-tube, for instance: this universal, uniform recipient, this non-object, this exemplification of the scientific strive for experimental transparency and control-as well as a microbe's habitat? What kind of a world (or non-world) is a laboratory, where everything we associate with everyday existence is systematically kept at bay, including everyday conceptions and convictions? What kind of existence is science as a profession? What kind of practice is laboratory work? How do scientists stand out towards the entities they study? Do they study things at all, or rather laboratory artefacts? Which metaphysical convictions are guiding (are materialising in) laboratory life, or questioned by it?

To address such issues, we must deepen our understanding of Heidegger's "method". Although the later Heidegger sees the quest for a rigorous method as symptomatic of the technoscientific enframing of nature as reproducible objectivity, the outlines of a method for philosophical reflection can nonetheless be discerned, also in his later lectures and essays, albeit a method that is developed along the way: gradually emerging as a road to follow, in accordance with the original Greek meaning of the term $\left(\mu \varepsilon \tau^{\prime}+\dot{o} \delta \varsigma \varsigma\right)$. This outline entails important components, such as: pay attention to language, e.g., to the history of the terms we use. Other important components are the dialogue (Zweisprache, Auseinandersetzung) with previous thinkers, the neighbourhood (Nachbarschaft) of poetry and thinking (compared to the distance between thinking and science) and the awareness of the provisional nature of our concepts, so that we are always underway towards language, knowledge, truth, etc. Also important is the backward step (the Schritt zurück), towards the moment of commencement (Anfang) of established ways of thinking. Heidegger's "method," I will argue, may deepen our understanding of contemporary technoscience, one of the most transformative 
and disruptive global forces of today. But a reflection on contemporary technoscience will also enable and necessitate a renewed confrontation (Auseinandersetzung) with Heidegger's own thinking.

Rather than being a commentary on Heidegger's oeuvre, therefore, the aim of this paper is to extrapolate Heidegger's way of thinking towards the present. How to practice "Heideggerian" philosophy today? The scholarship conducted here does not easily fall under the heading of "author studies". Rather, my purpose is to step back and reconsider Heidegger's efforts at developing a new way of questioning and thinking. My question is not how Heidegger interpreted technoscientific developments in the 1920s or the 1950s. Rather, the question addressing us here is how to consider technoscientific things and practices from a Heideggerian perspective today? This requires a reconsideration of Heidegger's method. As was already indicated, his views on "method" shifted quite drastically over time. In Being and Time (1977; GA2), for instance, but even more so in Basic Problems of Phenomenology (1975; GA24), dating from the same period, Heidegger speaks about method in a resolute and affirmative manner. Phenomenology is presented as the method of the science of ontology, the philosophical method par excellence. In later writings, the very aim of developing a methodology is discarded as unphilosophical, technical and hazardous. Methodology becomes associated with technical and calculative thinking, with research as an enterprise.

The prospects for unearthing a "method" for understanding technoscience, notably from Heidegger's later writings, may seem discouraging. Although these writings contain many careful interpretations of things like jugs and clogs, technoscientific entities (such as Sputniks or atom smashers) are discussed in a distanced manner, without paying much attention to detail. A Sputnik, according to Heidegger (1985; GA12: 165), travels at high speed through a non-world: through unworldly space, as an artificial entity. The question what kind of a thing a Sputnik really is, seems to be evaded.

In short, this paper addresses the question how Heidegger's method allows us to question contemporary technoscience as a practice. I will focus on a particular realm (Bezirk) of technoscientific inquiry, namely life sciences research. How to consider, from a Heideggerian viewpoint, technoscientific entities such as genomes or automated sequencing machines? How to understand life sciences laboratories as worldly-unworldly settings, and life sciences research as a global enterprise ("Betrieb")? Or should we discard the very idea of a Heideggerian method for studying contemporary technoscience as an oxymoron from the very outset? My answer will be that a Heideggerian method of questioning can be developed along the way and that his lectures and writings contain important hints which put us on a viable track. For instance, a Heideggerian philosophy of contemporary technoscience should not be practiced as a form of "espionage" (1975; GA24: 227). We should not study scientists in a secretive manner, "from behind". Could we study them from a position of proximity or "neighbourhood" (Nachbarschaft), so that philosophical reflection unfolds as a science-philosophy dialogue (Zweisprache), along the way? In the next sections, Heidegger's views on method will be explored in more detail. 


\section{Heidegger's Early Views on Method}

The issue of "method" is already addressed in Being and Time, where Heidegger (1977; GA2) explains that a philosophical (phenomenological) method of inquiry entails an analysis of Dasein (human existence as being-there) and a "destruction" of the history of philosophy, enabling a return to and recovery of our primary experience and interpretation of being. Dasein is not presented as an isolated "thinking ego" facing an object, but as a form of existence structured by intentionality: dwelling in a world, standing out towards and uncovering concrete things, which are part of a coherent and meaningful ambiance. Most of the things we encounter are useful things, ready-at-hand, belonging to (and referring to) a particular context (a home, a workshop, etc.). We handle these things $(\pi \rho \alpha \dot{\gamma} \gamma \mu \alpha \tau \alpha)$ in everyday practice, but philosophy (phenomenology) urges us to take a step backwards, to question and disclose their way of being. For instance: a glass (with a flat bottom) and a table (with a flat surface) refer to one another, as the glass is fashioned in such a way that we may safely put it on a table. They are part of (refer to) a particular setting or constellation. Before taking up a glass, we are already there.

If we extrapolate these considerations to contemporary life sciences research, the laboratory becomes an ambiance where entities such as test-tubes and petridishes, but also our practices of handling them, become part of a meaningful whole. By taking a step backwards, we distance ourselves from preconceived interpretations, such as the segregation between subject and object, natural entities and artefacts. We approach laboratory life from within, structured in a particular manner, entailing a particular form of intentionality.

Some of the things we encounter are put to use as signs or symbols. Heidegger uses a nice urban example from the 1920s: an adjustable red arrow used by truck drivers as a sign to indicate the direction in which the car is going to turn. We are not supposed to care too much about the sign as such (we should neither stare at it, nor ponder its construction) but rather be aware of the movement the vehicle is about to make. In short, we interact with and are addressed by multiple things in various meaningful ways. Philosophy (phenomenology) studies this world by analysing the ways in which these entities present themselves to us. Whereas some things can be used for certain activities in a certain manner, they also point beyond themselves towards the broader setting. This function of referral (Verweisung) may become formalised to such an extent that the thing becomes a sign or symbol (Zeichen), signalling things to come, or things at a distance (Heidegger 1977; GA2: 104). They can only function as signs insofar as Dasein exists, however: discerning and interpreting them as signs. This again is something to consider when visiting laboratory settings, where many entities indeed function as signs: as signalling or measuring instruments, referring to something else, something which is not yet there, or which is kept in vitro. In other words, what applies to Dasein as such also applies to laboratory life: human existence is inherently connected to the way of being of the things we encounter and we recognise ourselves in our handling of them.

We encounter a similar view on method in The Basic Problems of Phenomenology (1975; GA24), a seminar dating from the same year 1927. The aim is to 
learn students to practice phenomenology, to become practicing philosophers, to join the practice of thinking ("mithandeln lernen": 1). The focus is on the How of philosophical inquiry ("Forschung"). Phenomenology, Heidegger argues, is the method of a "scientific philosophy" (1927/1975;GA24: 3), allowing philosophy to become a science. Whereas the "positive" sciences study various types of beings, philosophy is the science of being as such: studying the way of being of beings in a systematic (phenomenological) manner. Phenomenological analysis commences with studying concrete beings, but from a sideways perspective as it were, focusing on their way of being. Phenomenologists may study a particular tree, for instance, not in order to understand photosynthesis, but because they are interested in the way of being of living beings. Being is only accessible via the analysis of concrete beings. The essence of the phenomenological method is the step backwards: from investigating concrete beings (the work of specialised sciences) towards questioning their way of being as such, so that being as such comes into view.

Thus, phenomenology studies the basic structure of particular ways of being. Dasein, for instance, is structured as Being-in-the-world, as intentionality: standing out towards other beings (things). Our intention is fundamentally oriented towards disclosing other beings. At the same time, we are what we do and we recognise ourselves in our handling of things in our environment. To understand craftsmen, we must visit their workshops. When we look at our watch, we do not see the watch as such, but are oriented towards things to come: the time we still have before a particular event takes place, unless we are watchmakers, for then we focus on the watch as such. We analyse Dasein via our interactions with our environment, requiring care and effort.

What lessons can be learned for understanding technoscience from these early writings? First of all, we see technoscience as a practice, unfolding in a concrete, meaningful context. We should not only read about science, but visit scientists in their laboratories (literally: workshops) to consider the ambiance in which technoscience is practiced and how scientists stand out to and are addressed by things. We have to be there, albeit in a particular manner. Philosophical reflection does not amount to "espionage" (Heidegger 1927/1975; GA24: 227), —which, perhaps, is how social scientists or STS scholars study science: seeing scientists and scientific practices as targets of research. Rather, the focus should be on the intentionality of the scientists themselves, on the way of being of the laboratory items handled by them. Are these entities tools, signs, or artefacts? Do they constitute a particular form of objectivity? Scientists are studied by studying their research practice from within as it were: envisioning the things they handle, the extent to which they themselves are captured by and merge into ("existierend aufgehen in") these things. The things they intentionally handle may not yet be recognisable items, but laboratory artefacts: uncanny neo-things, whose way of being still has to be explored.

The most important methodological concept put forward by Heidegger in the1920s is the "formal indication" ("formale Anzeige"). The meaning of the phenomena we encounter cannot be fully disclosed, can only be indicated or hinted at in a provisional manner, so that their meaning must be explored more fully along the way. To start with an explicit definition would put us on a questionable track, 
endorsing accepted interpretations while obfuscating other possibilities. Although a formal indication initiates and guides the explication process, it does not entail any preconceived convictions. It is a precautionary measure (Vorsichtsmaßregel, 1920/1921/1995; GA60: 64). A formal indication is a revisable way of pointing to particular phenomena, deflecting from uncritical lapses into established interpretations that foreclose further explication (Dahlstrom 1994). Philosophical concepts are indications pointing to a concrete task, to be performed through philosophising while foregoing pre-emptive characterisations of the phenomenon's way of being. The phenomenon is not given as something already understandable, but can only become understandable via questioning and working through, bracketing customary ways of considering things.

The formal indication inverts the "normal" perspective, the mainstream way of posing questions, and opens up a movement of retrieval which runs counter to accepted (unquestioned) manners of capturing phenomena, notably in science. For Heidegger, the purpose of this reversal of the taken-for-granted attitude is to avoid the kind of objectification that characterises the positive sciences. Philosophical concepts are non-objectifying. Philosophy is re-iteration, retrieving the path (iter) towards the phenomena that call upon us, indicating a task to be carried out, via thinking as an exercise in retrieval. A continuous methodological reflection is inherent to this non-objectifying way of speaking and thinking. Formal indication is Heidegger's version of docta ignoratia. ${ }^{1}$ We point to the phenomena at hand, whose meaning may seem self-evident, and to possible directions of interpretation, but in such a way that we at the same time acknowledge that we do not really know what we are actually saying when we use words such as "thing," "thinking," "being" or truth," and that we should allow ourselves to be summoned by these words, that we should be prepared to travel the difficult path towards them. The term "formal" (used in the context of a discussion of Husserl's concept of formalisation) actually means something like "provisional". Heidegger refrains from re-using this term in later texts, but the attitude as such remains very much alive, not only in Being and Time (Dahlstrom 1994; Streeter 1997; Shockey 2010), but also in later writings.

\section{Heidegger's Method After the Turn: First Exploration}

In later writings (after the Kehre), Heidegger's attitude towards "method" seems to change dramatically. Whereas in 1927 he resolutely presented philosophy as a rigorous science, in later writings he rejected this idea: apparently a radical turn in his path of thought (Glazebrook 2000). And whereas in earlier writings he seemed bent on developing a rigid method, Heidegger now identifies method with technology and the calculative rationality of the natural sciences. He emphatically discards "methodological considerations" in favour of the experience of authentic thinking (Heidegger 1985; GA12: 168). Indeed, the received view is that Heidegger abandoned the quest for a rigid method after the turn and that, in his late philosophy,

\footnotetext{
1 See: "Nur dies Eine ist zu wissen, dass wir nichts wissen, solange wir... etc." (Heidegger 2009: 88).
} 
his manner of proceeding is "relieved of the claim to be methodical" (Thomson 1999: 170). In contrast with his earlier emphasis on the importance of method, Heidegger now appears to reject the very idea of a "philosophical method" as oxymoronic (1959/1985; GA12: 171). Although the term method is derived from óós ("the road, the way"), in Heidegger's later writings, the gap between his own "way" of thinking (off the beaten track) and the "methodology" of the positive sciences seems to widen (Von Herrmann 1990). Or should we rather say that the claim that the later Heidegger has no method is mistaken, and that his later writings contain important methodological reflections (Dahlstrom 1994: 779)? In the following sections, the latter option will be endorsed. Heidegger's aim, I will argue, is to recover a forgotten (albeit non-technical, non-procedural) understanding of method as "being underway" (see, Thomson 1999: 174). Heidegger's later writings contain important hints for a new beginning, also where method is concerned, pointing out a new way of practicing philosophy, although he remains adamant in his refusal to adopt the term "method" for his approach. Similar to Gadamer (1990), Heidegger's reluctance towards method should not be considered as a denial of the importance of methodological concerns, but as an insistence on philosophical understanding as an explorative, dialogic, practical and situated activity.

One important methodological hint is that we should carefully listen to and pay attention to language (1985; GA12 and elsewhere). Language speaks, and in order to experience the voice of language, and to become sensitive to the way we are addressed by language, we should pay attention to the genealogical vicissitudes of the words we use, so as to discern and recover their primary meaning, which eroded over time, although their original meaning somehow still shines through even in our perverted and inconsiderate use of them.

Closely connected with this is another important dimension of Heidegger's way of thinking, namely his recourse to the first beginnings of Western philosophy, ${ }^{2}$ Heidegger's recurring efforts to recollect and rethink the daybreak of early Greek thought, his attempts to reread the sayings of ancient Greek thinkers in such a way that their language becomes audible again, is brought nearer to us again, so that, to some extent, their groundbreaking thoughts become thinkable (accessible) again.

Another hint is to pay attention to poetry, to the language of the poets, not any kind of poet, but the "daring" ones, who dare to expose themselves to the address of language (1946/1977; GA5: 316, 318). Lines of Hölderlin poetry are read in the same careful manner as Heidegger reads (recollects) sayings by Heraclitus or Anaximander. What is obfuscated in calculative rationality, may be retrieved in poetry. Science itself has fallen under the sway of technology, but appears to be unknowing of its own predicament. We should therefore consider the poetry of daring, untimely poets in a thinking manner, sensitive to how their poetry reveals a more poetic way of encountering things, or even the secret of being as such. Poetic art may prepare

\footnotetext{
2 See for instance his rereading of sayings by Parmenides, Heraclitus, and Anaximander in GA5 and GA7. Heidegger's "Rückgriff auf den ersten Anfang der abendländischen Philosophie" (Gadamer 1990: 261).
} 
the way for a new beginning, instigating a new "method" even: a radically new way of philosophical questioning (Blok 2015: 6; Blok 2020: 28).

Heidegger also endorses the phenomenological adage "To the things themselves," but in a way that is different from Husserl. While for Husserl the translation of Sachen with "things" is somewhat misleading, in Heidegger's works we find multiple efforts to approach and come to terms with concrete, tangible things, like hammers, clogs and jugs, in a sensitive, careful manner, so that our questioning of them does not amount to an assault upon them (Owens 1987).

Can we consider such hints (e.g., pay attention to language, listen to thinking poetry, heed the way in which daring poets allow language itself to speak, step back to recollect the commencement of Western thinking, etc.) as points of departure for coming to terms with technoscience? They outline a path whose orientation seems fairly remote from the experimental practices that are actually conducted in laboratories of contemporary life sciences research. An important motive for Heidegger's later resistance to "method" is his identification of the term with the methodology of technoscience: technical procedures for procuring quantifiable results, enframing nature as a mere resource for exploitation. Whereas the later Heidegger fosters proximity (Nachbarschaft) between poets and philosophers, the science-philosophy divide widens. ${ }^{3}$ The way in which thinking poetry and poetic thinking allow the world to appear (allow things to present themselves to us) seems juxtaposed to the way in which technoscience obliterates its objects, to the way in which technical power reduces things to mere "objectivity".

On the other hand, precisely this gap or tension, between poetry on the one hand and calculative, technoscientific rationality on the other, seems to call for something like a "comparative phenomenology". Whereas Heidegger speaks about poetic, rural, artisanal things (like jugs and clogs) in a detailed and careful manner, technoscientific entities are mentioned in passing. Heidegger mentions "this thing Sputnik," for instance, this miracle and dream of modern technology and planetary computing (1985; GA12: 165) that travels at very high speed through world-less space, lighting up momentarily in Heidegger's own text, but without being really considered. Why is this entity, this high-tech novum of planetary significance, not fathomed in a much more careful, extensive, methodological manner? If, in earlier works, Heidegger discusses urban technical entities such as traffic signs (1977; GA2: 78) or the Marburg central train station (1975; GA24: 98), what is now holding him back? What is the reason for this withdrawal? If the aim of philosophy is to come to terms with the present (and the planetary hazards entailed in the current situation, the current global crisis), why not question the enigmatic way of being of Sputniks and other technoscientific contrivances (besides, and in contrast to, the way of being of jugs and clogs)? Indeed, why not analyse Sputniks first and foremost? How to acquire a more precise understanding of the vicissitudes of technoscientific objects in the context of scientific research as an objectifying praxis?

\footnotetext{
3 "[Es] gilt zu erkennen, dass der Abstand zwischen dem wesentlichen Wissen und den Wissenschaften ein unendlicher ist. Hier gibt es keine Brücke” (Heidegger 2009: 118).
} 


\section{Heidegger's Discourse on Method: On Our Way Towards Technoscience}

As a first introduction into Heidegger's method in later writings, the essay "What is Thinking?" (1955/2006; GA11), seems an obvious place to start. We only genuinely think when we are called into thinking, into the practice of questioning, Heidegger argues. Thinking begins when a question puts us on a path, urging us to follow this path in a careful manner (with Sorgfalt), paying attention to hints (Hinweise) such as: considering carefully the words we use, notably the word philosophy, recollecting the origin and historicity of such terms. The very word "philosophy" already opens up a path. It is a path, entailing a question-what is philosophy? — calling us into thinking. The "what is"-question $(\tau 1 \dot{\varepsilon} \sigma \tau 1 \nu)$ already entails a particular practice of questioning, moreover, inaugurated by Socrates, Plato and Aristotle. As if their voice, their way of practicing philosophy, still echoes in the term, provided we pay attention to it. We are called back to this type of questioning. By paying attention to language, we are already underway. Our task now becomes to respond to the question in such a way that our question corresponds (Entsprechen) to the logos at work in this questioning practice. Philosophy means being underway as a particular kind of activity, hinted at by Aristotle's term غ̇vé $\rho \gamma \varepsilon 1 \alpha$-which literally means being-atwork, performing-a-task as human beings, namely: thinking. Being underway to thinking implies that we have to move towards this way of being (entgegenkommen), by joining a conversation.

If we try, along these lines, to come to terms with contemporary technoscience, we should first of all pay attention to the term "technoscience" itself and notice that it already reveals an important experience, namely that science has fallen under the sway of technology, becoming an inherently technical praxis. Rather than seeing technology as "applied science," we should see science (both experimental and theoretical science) as inherently technical, as a practiced enforcement ("Vollzug") of technology (see, Heidegger 1944/1945/1995; GA 77: 6 ff.; see Heidegger 2009; GA76: 125). Science is technoscience because its methodology is under the sway of technicity. Apparently contradictory tendencies, such as increased uniformity and levelling on the one hand and increased specialisation on the other, are both symptoms of technicity. Both are enforced by the power of technology, tying researchers to their specialised equipment (Heidegger 2009; GA76: 124, 138, 160: 259), similar to how workers are tied to their specialised machines. Notwithstanding specialisation, all technologies materialise the same metaphysical claim, namely that nature must be objectified, giving rise to institutionalised forms of research organisation, be it of the pragmatic-American or of the Marxist-Russian variety (Heidegger 2009; GA76: 269). ${ }^{4}$

Extrapolating these insights into the context of contemporary life sciences research, one could argue that technoscience emerges as a particular way of

\footnotetext{
${ }^{4}$ In a similar vein, Heidegger critically reviews the way science is organised by Nazism, notably the plans for building a technical university in Chiemsee: a model institute for educating the future NSDAP elite, initiated by Reichsorganisationsleiter Robert Ley, head of the German Labour Front (2009 GA76: 163).
} 
enframing and objectifying life and nature, namely as bioinformation: something which can be handled in a computational manner (sequenced, deposited, digitalised and edited via big computers). CRISPR-Cas9, for instance, could only be discovered because living (microbial) nature was already enframed as information networks, channelling and circulating data.

Heidegger's short essay is a concise version of a more extended series of reflections entitled What is Called Thinking (Was heißt Denken?). This lecture course, presented in 1951 and 1952 (Heidegger 1954/2002; GA8), can perhaps be regarded as Heidegger's "discourse on method". A philosophical way (ódós) of questioning is outlined. Heidegger's aim is to guide us into thinking. We are called upon to learn the practice of thinking, paying due attention to that what summons us into thinking. We are invited to enter the road of thinking by paying attention to the questioning call: the question that is calling out to us.

These lectures again contain important methodological hints. First of all, Heidegger indicates that we learn to think along the way. We only learn to think by beginning to think, taking the road in response to the call. To find out what "thinking" means, we cannot commence with a clear definition. Rather, we set off (off the beaten track), guided by hints that provide us with a sense of direction. We cannot build on available knowledge but have to start anew. We think we know what thinking is, but the first thing to acknowledge is our lack of understanding, as the accepted way of thinking is utterly questionable.

Another important hint is that, if we want to learn to think, we should not rely on science, especially not on cognitive psychology or neuro-science. Although science produces staggering amounts of insights into brain processes-making brain waves recordable, via acoustic amplifications, tracing their course electronically, via plotted curves, etc. (Heidegger 1954/2002; GA8: 17) -, such research already builds on a rather specific preconception of what thinking means. It is a research practice under the sway of technicity. Science does not think about its own way of thinking, but adopts a single-track form of thinking to engage with standardised, uniform objects (Heidegger 1954/2002; GA8: 58), while its technical language is replete with neologisms and acronyms. Therefore, we must question the questionable logic of science and open up to other, currently precluded possibilities (see, Glazebrook 2012).

Another hint to guide us along the path is: pay attention to the history of the terms we use. This notably applies to our primal vocabulary: words like "thinking," "thing," "life" or "method". In close connection with this, we have to confront the thoughts of great thinkers, not by simply quoting them, but by entering into a real dialogue with them, recollecting their thoughts, but also the unthought, that which they did not explicitly think, but which is nonetheless audible, discernible, for those who pay attention. This questioning dialogue, rethinking their thoughts, entails an active attitude of confrontation (Auseinandersetzung). Notably, we should return to the beginning of Western thinking in ancient Greece, when thinkers for the first time responded to the questioning call, articulating their primal thoughts, albeit in a poetic and paratactic (rather than syntactic) manner. But we may also engage with thinking poets, whose sayings contain important hints as well. In order to be able to respond to the questioning call and to 
discern the calling question, we have to listen carefully, becoming responsive to what is calling us into thinking, so that our thinking may correspond to this call.

Although Heidegger is primarily concerned with outlining a philosophical way of thinking, he also develops (albeit in outline) a philosophical understanding of science as a particular (and particularly questionable and obfuscating) practice of thinking. A specific logic seems at work here, and philosophers may become the careful listeners, able to discern the questionable tenure of this logic. First of all, science has become technoscience: decisively technical. Research has fallen under the sway of technology, has evolved into a decidedly technical pursuit (compared to the sober "handiwork" of thought), evolving into a global force dominating Planet Earth. This threatening predicament is a question of thinking and language too, Heidegger maintains, for without Western logic, based on particular interpretations of words such as "thinking," "reason" and "truth," there would have been no airplanes, no atomic energy, no Enlightenment, no technoscience (1954/2002; GA8: 170).

Although What is Called Thinking contains promising hints for questioning contemporary technoscience, these remain provisional indications. Rather than providing us with a full-fledged, standardised and validated methodology (which would deflect from thinking), these hints urge us to develop a questioning style of thinking along the way, as we proceed, step by step, listening carefully to the language of science, to the way this language speaks, and induces its practitioners to speak.

Suppose that we now enter a life sciences laboratory. Would these indications allow us to find our way and put us on a track? First of all, we have to relinquish all preconceptions, realising that we do not know what "laboratory," "life" or "technoscience" is. Such terms merely initiate our efforts, and our pathway is bound to be a circular one (Kreisgang, 1935/1936/1977; GA5: 3), recurring again and again, although the etymological connection between "laboratory" and work (manual labour) may serve as a first hint. A laboratory contains many things, and laboratory entities often function as signs, as signalling measuring instruments, referring to something which is not yet there, or which is evolving in vitro. As we enter such an environment, established concepts, such as the term "instrument," should not be taken for granted. They fail to capture the-way-of-being-a-thing, the thingness of such items. In these established notions, violence is at play. By thoughtlessly using such terms, we fail to recognise that violence has already been done to the thingness of these things. All these conceptions and assertions, positioning themselves between the things and us, must be set aside, so that things can be truly encountered. Established notions must be circumvented to forego the assault (Überfall) on things entailed in them (1935/1936/1977; GA5: 10).

What is striking about laboratory entities is that they tend to be anonymous things, manufactured in a precise and uniform manner, without any visible traces of individual involvement. Precisely for that reason, an encounter seems a hazardous exercise, phenomenologically speaking, because how to engage with items which presuppose a rather elaborate, preconceived manual or script? The laboratory setting is urging us to approach such objects and instruments in very specific and preconfigured ways. Is it at all possible to take a step backwards, towards a situation where this way of approaching things was just beginning to unfold? While entering a life 
sciences laboratory where practices such as genome sequencing and gene editing are performed, what could serve as a moment of commencement?

Perhaps we could step back to Gregor Mendel's primal experiences during the 1860s, considering his sober formulas as the life sciences version of pre-Socratic sayings: original efforts at explicating an experience which, at that moment in time, was not yet overtaken by established technical conceptions. Could Mendel's monastery garden be considered a clearing, an open site in the midst of being (1935/1936/1977; GA5: 40), where the future objects of genetics and genomics made their appearance for the first time, were encountered for the first time in a certain manner, became accessible in a certain manner? Mendel's garden as the paradigm of life sciences experiences, the moment of commencement of an "epistemic culture" (Knorr Cetina 2002), and Mendel's menial practice as a pathway to be reiterated by us, in order to encounter the present? Such a detour, I would argue, may indeed help us to further our understanding of genomics, gene editing and similar life sciences endeavours that are currently unleashed, as massive assaults on living beings, stripping them of their significance, literally obliterating them, replacing them by nucleic code, by letters (Zwart 2016), positing operations such as replication, transcription and translation as the key processes of life (Lemmens 2008: 149). Mendel introduced a particular form of literacy to refer to dominant and recessive factors (Aa, Bb, etc.), a signifying practice which subsequently evolved into computational biology: high-tech attempts to capture living beings in terms of a 4-letter alphabet (ACGT). All things we encounter in a life sciences laboratory consistently refer to this process of obliteration, which is evidently connected with technology as a strive for dominance over the biosphere. This could be a first outline of a Heideggerian interpretation of contemporary laboratory life. It would allow us to perceive laboratory practice from a sideways, oblique perspective (Zwart 2017), for rather than on proteins, nucleotides or genes, our intentionality would be focused on the way such entities are objectified and visualised, enframed and disclosed, via preestablished conceptual repertoires. Such an exercise may help science to overcome its conceptual phobia, its "Begriffsangst" (Heidegger 2009; GA 76: 58), its obsession with data and facts. Rather than espionage, it would entail a dialogue (Zweisprache), a critical confrontation (Auseinandersetzung) with scientists at work in such a setting.

Let this serve as a first exploration. I will now reiterate the question of method by focussing on three dimensions of technoscience: on objectified objects of technoscience, on the experimental setting of technoscience and on the global enterprise of technoscience.

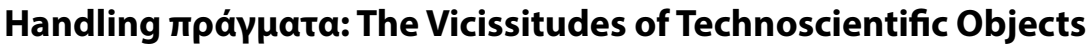

In Heidegger's later writings, we encounter rudimentary analyses of technoscientific entities, for instance in his essay Das Ding (1950/2000; GA7). Technoscience, Heidegger explains, produces things like airplanes, broadcasting technologies, cinema and the like, but although these technologies seem to entail an obliteration of distance, this process will not bring the things themselves nearer to us. Quite the 
contrary, our sense of spatiality becomes impoverished if all distances are transfused into undefined, homogeneous space. In everyday existence, some things have retained their proximity to us, but this does not seem to apply to technoscientific artefacts.

The jug is such a thing, Heidegger argues. What is a jug? And why is it different from, say, a test-tube or a Bresser telescope? A jug is a vessel created to contain emptiness: a hollowness that can be filled, with wine or water for instance. What does science have to say about such a thing? Science can measure, in a rather precise manner, the amount of fluid the jug may contain, can define its mathematical and physical features. In doing so, the jug as a jug, as a meaningful entity, becomes obliterated. To address the question what kind of thing the jug is, we have to forget about science and the metaphysical convictions concerning thingness on which it builds, and start anew. Via careful analysis, Heidegger brings to the fore that the jug is a thing which brings people together, sharing gifts of wine and water. A technoscientific (quantitative) analysis of jugs would have the opposite effect: would distance (estrange) us from the thing.

If we extrapolate these analyses to contemporary technoscience, technoscientific things evidently diverge from this. Instead of assembling (bringing together), laboratory items such as microscopes, for instance, seem to segregate. They introduce a rupture between subject and object, inside and outside, in vitro and in vivo, science and the public, knowledge and prejudice. A microscope will not bring microbes nearer to us, but rather creates distance: not in the physical sense, but by introducing ontological distance: between microbiologist (subject) and microbe (object). An instrument has been inserted between the two, allowing the former to zoom in and out, to objectify. Yes, a microscope provides a window into the microbial world, feigning proximity, but at the same time separating and segregating microbes and humans, ontologically speaking.

What happens when microbes are spotted through a microscope? To answer this question, Heidegger urges us to take a backward step (Schritt zurück), away from explanatory (i.e., technoscientific) thinking and into recollective thinking (andenkend denken, 1950/2000; GA7: 183). Techno-scientists are intentionally focussed on microbes. These living entities seem to be calling out to them, but in what manner? It is only by taking a step backwards that we may consider (from an oblique perspective) the difference between a careful handling of things like jugs and the calculative manipulation of technoscientific things like test-tubes (and the microbes that inhabit them), or PCR contrivances, or automated sequencing machines, unleashing the possibility of amplifying, sequencing, modifying and editing microbial segments of DNA.

Heidegger himself prefers to write about jugs and clogs, rather than about technical contrivances. If he speaks about the latter, he usually refers to highly complex entities, such Sputniks and atom smashers, rather than to more every-day laboratory items, such as microscopes or petri-dishes. He withdraws himself from what would amount to a comparative phenomenological analysis of life-world things versus laboratory artefacts. Meanwhile, however, laboratories have exploded, have proliferated, have become interconnected to such an extent that all the world is now becoming one gigantic lab. The global environment has been transformed into a living 
laboratory of terrestrial size and scale, a global web of intelligence, a noosphere. Can we still withdraw from a close analysis of technoscientific things? Sequencing machines and DNA sensors have multiplied and proliferated, while microbes and genomes (including human genomes) are being assembled, amplified, studied and manipulated virtually everywhere. Is this not crying out for a philosophical analysis along Heideggerian lines? If we see this development as worrisome, for instance, what exactly is there to worry about? Various types of discourse (bioethics, STS, ICT ethics, etc.) are already in full swing, addressing issues such as privacy, benefit sharing and risks, but is this indeed the way to genuinely question the questionability of emerging technoscience? Or is something lost or overlooked, even in these reflexive ("critical") types of discourse? In order to address such questions, we need to analyse the situation in a careful, methodological manner. Why should Heidegger urge us to withdraw from such a project, opting for releasement (Gelassenheit) instead? The absence of an explicit explorative confrontation (Auseinandersetzung) with technoscience may even impoverish philosophical thinking, turning it into unworldly "quietism" (Philipse 1998: 309; Blok 2013: 287). And yet, as Kockelmans (1985) already pointed out, Heidegger himself was well read in science, participated in scientific $\mathrm{PhD}$ defences, engaged in discussions with Heisenberg, Von Weizsäcker and others.

We cannot refrain from questioning technoscientific things and technoscientific practices, if only because, increasingly, they pervade the global techno-cultural ecosystem. A phenomenological analysis requires us to enter the global network of laboratories that is currently evolving precisely because we are already there. What kind of entities are objectified, datafied and studied and in what manner? What could be the threats involved? What kind of intellectual, rather than physical, contamination could be entailed in such an endeavour? By asking such questions, the focus of our intentionality has already shifted from object to ambiance: to laboratories as technoscientific settings.

\section{Laboratory as (Worldly-Unworldly) Settings}

A high-tech life sciences laboratory seems an uncanny site, a locus suspectus, under the sway of technification, objectivation and datafication. A site which, ideally, claims to be free of contamination is actually pervaded (contaminated) by the logic of calculative thinking, the very opposite of a Heideggerian country path. Still, comparisons should not be framed in terms of "contaminated" versus "pure," for a Heideggerian approach entails the awareness that our access to the world is "always already contaminated" (Blok 2020: 18), regardless of whether we opt for laboratories or forest roads. Philosophy must entail the willingness to bracket all pre-existing conceptions about things, seeing all views as "views from somewhere". A Heideggerian analysis of, say, a laboratory for microbial research, might reveal precisely how cutting-edge microscopy is enframing the microbial world, allowing microbes to appear to us and present themselves to us in a very particular manner (e.g., as carriers of genetic information). Rather than bringing microbes nearer to us, this type of technology may rather create distance, positing the microbe as an 
object (Gegenstand), an adversary even, enframing microbial nature as a reservoir for exploitation, for bioprospecting (i.e., the quest for procurable and patentable biomaterials and genes). At the same time, an act of disclosure seems at work as well. A window is created, providing access into an otherwise obfuscated realm of being. Can scientists be genuinely addressed by this emerging microbial world?

At first glance, Heidegger assesses technoscientific disclosure in pejorative terms. For Heidegger, technoscience is an assault on nature, as exemplified by modern quantum physics, where objects are literally obliterated, in cloud chambers ("Wilsonkammer," 1953/2000; GA7: 55), so that these Gegenstände are brought fully under technical control, seemingly deprived of all possibilities of resistance (1953/2000; GA7: 55). What such contrivances bring to the fore is a hyper-technical interpretation of nature. Against this backdrop, how would a Heideggerian visitor describe a microbiology or genomics lab today? What could be the added value of such a visit?

From a Heideggerian perspective, a life sciences laboratory emerges as an ambiguous ambiance as we have seen. On the one hand, a whole dimension of nature (of being), completely ignored in day-to-day existence, is painstakingly revealed, disclosing that planet Earth is first and foremost a microbial planet. On the other hand, this microbial world is enframed in a particular manner. Rather than in microbes as such, contemporary microbiologists are probably interested in their genomes, using automated sequencing machines to identify, amplify and modify microbial and viral DNA and RNA. ${ }^{5}$ Microbes are enframed as biomolecular machines. The moment of $\dot{\alpha} \lambda \dot{\eta} \theta \varepsilon \imath \alpha$ which may once have befallen pioneers such as Antony van Leeuwenhoek, spotting microbes for the very first time in drops of rainwater, with the help of selfmade microscopes, has been obfuscated by decades of microbiological experiments, resulting in whole libraries of microbial publications and terabyte data-sets. And yet: if we, as philosophers, feel prompted to raise the question "what kind of thing is a microbe?"-what kind of being is an Escherichia coli bacterium for instance-we inevitably need to (visit) technoscientific laboratories, to study the kind of research that is practiced there. At the same time, via a backward step, our aim should be to move beyond this practice (and the type of questions it is addressing, the type of answers it is providing), for instance by recovering the beginning, the stupefying Anfang, the moment of disclosure. This may be done, for instance, by consciously engaging with Van Leeuwenhoek's careful hand-made drawings of microbes. An explorative confrontational and comparative philosophical exercise could indeed consist in comparing these impressive drawings with their technoscientific counterparts: the glossy, high-tech images produced by contemporary technoscience today, on display on PowerPoint slides at international conferences or in journals such as Cell or Nature.

Why did Heidegger not engage in this type of research himself? What was the ground of his reluctance? Would philosophical questioning, as a critical practice, be fostered or endangered by taking such an "empirical turn"? Rather than spying on

\footnotetext{
5 Heidegger mentions viral research as an instance of switching ("Umschaltung") from biology to biochemistry, and nowadays, one could argue, we notice a similar switching, even more radical perhaps, towards computational bio-informatics (2009; GA76: 128).
} 
researchers from a social science perspective, peering at them through a key hole as it were, philosophers should engage in a dialogue with these practitioners, from a position of close proximity or Nachbarschaft. While empirical social sciences enframe microbiologists themselves as objects or adversaries, philosophical conversations offer a common pathway, a Feldweg-Gespräch (Heidegger 1944/1945/1995; GA77), where philosophical questions concerning technoscience are explored in dialogue. Or should scientists consider engagement with philosophy as a contamination of their research and vice versa?

What makes a Heideggerian consideration of laboratories even more urgent is the awareness that it has become impossible to regard them as secluded, insulated sites. They proliferated to such an extent that the socio-economic environment has evolved into a global laboratory for producing and circulating bio-data on a massive scale. Not only in the sense that our global environment is pervaded by technical contrivances such as radios, earplugs and cell phones (Babich 2018; Fidalgo 2009) but also in the sense that virtually all societal settings have become "living laboratories" for experimental research. We are all research subjects now and our behavioural repertoires are monitored quite closely, including our click-behaviour as digital consumers. All the available information is analysed, everything is relevant, however trivial it may seem (Zwart 2016). Rather than being secluded, protected sites, laboratories have expanded to encompass everything. The basic topology of the laboratory has changed from an unworldly setting into a collective ambiance of intelligence (voṽs).

Heidegger was quite right when he suggested cybernetics as the new paradigm of technoscientific research, more optimally poised to understand our global world than philosophy itself (Lemmens 2008; Nugent 2014; Zwier and Blok 2019). In a cybernetic global environment, human beings are enframed as information devices (producing, processing and analysing information continuously). Cybernetics is the universal science, while philosophy is becoming irrelevant (2017; GA89). Studying human behaviour via feedback mechanisms makes humans transparent, even though, precisely as thinking beings, open to the call of Being, they are effectively obliterated. Heidegger is not criticising cybernetics as a performative science. What is questioned is cybernetics as a metaphysics, i.e., as an answer to the question what human beings really are ("information devices"). Cybernetically speaking, the world is evolving into a global web-like device for procuring, processing, circulating and validating information. This is what all beings have in common, microbes as well as humans: they are circuits of information. The task of philosophy would be to explicate this metaphysical claim, so that we may withdraw from it (Entzug) and remain open to other possible interpretations. Rather than being "seized" by the dictates of information gathering, philosophy assesses how informatics/cybernetics is reframing our world-picture and mobilising humanity on a global scale.

This also allows us to position a Heideggerian phenomenological method visà-vis sociological, anthropological and ethnographical approaches, often referred to as STS. On the one hand, we notice convergence. Heidegger's emphasis on the technicity of technoscience already offers a bridge (Hottois 1984; Lemmens 2008; Kastenhofer and Schwarz 2011; Zwart 2020). Moreover, from a Heideggerian perspective, technoscientific contrivances (such as microscopes) give rise to objectification, bringing microbes closer to us, literally into view, while at the same time 
segregating scientists as subjects (the scientific gaze) from their objects (microbes), as we have seen. But such contrivances also serve as "inscription devices" (Latour and Woolgar 1986), literally obliterating the object, as we have seen, replacing material entities with symbols, measurements and codes that can be quantitatively, stochastically and digitally handled. Thus, epistemological questioning ("Begriffsarbeit") addressing tangible entities, fostering reflection on concrete practices and things instead of addressing such issues in abstract philosophical terms, in fear of contamination (Knorr Cetina 2002; Rheinberger 2006; Stahl 2018: 10). Still, for Heidegger, philosophy will never mean studying "daily practices" of "research cultures" (Lynch 1985; Knorr Cetina 2002) from a sociological, anthropological or ethnographical (third person) perspective. Rather, thinking for him means: questioning the grounding ontological convictions at work, the ways-of-being of technoscientific artefacts, via confrontational dialogue ("Auseinandersetzung"). Although Heideggerian ontology and STS reflect radically different attitudes, they inevitably encounter one another (underway to the laboratories of technoscience) and may therefore mutually inspire and challenge (or irritate) one another.

\section{Technoscience as a Global Research Enterprise}

Another pivotal text, namely The age of the world-picture (Heidegger 1938/1977; GA5) likewise addresses objectification and obliteration of technoscientific objects, while calling attention to technoscience as a global endeavour. Technoscience enforces phenomena to come forward via objectification (Vergegenständlichung). According to Heidegger, science is basically research (Forschung; 1938/1977; GA5: 79; see , 2009; GA 76: 123), i.e., technoscience: grounded in technology. Its methodologies are procedures for establishing and securing claims by enhancing validity, objectivity and replicability. Technoscience no longer calls for erudition (scholarship, Gelehrsamkeit), but rather entails a painstakingly planned and institutionalised practice. Although scientific discovery may commence as small-scale, careful, creative, and menial research practices, conducted by pioneers such as Gregor Mendel or Rosalind Franklin for instance (Zwart 2013), Heidegger discerns an inherent force at work in technoscience, pushing it towards developing into a large-scale, anonymous enterprise (Betrieb) whose objective is the objectification of nature: an enterprise on an industrial scale, even when performed on university campuses, where the difference between classical and technical universities evaporated. Research equipment is industrially produced and this includes the assembly line production of cell cultures and research animals (e.g., nude mice or Wistar rats) as technoscientific commodities (Rader 2004). Research is designed in a rigorous manner and this design (Entwurf) determines how research unfolds in particular fields. Science as research is conducted in accordance with rigorous methodological procedures (1938/1977; GA5: 79) in such a way that optimal conditions are created to ensure that research phenomena can be secured in an exact, uniform, predictable and replicable manner. This is exemplified by experimental practice, aimed at securing the precedence of the methodological procedure over the entities that are studied. Indeed, the methodological procedure determines and secures how these entities ("objects") are allowed 
to appear. Ultimately, the objective of science is to ensure that more research can be done in the future (technoscience as a self-serving industry). In short, what is driving scientific research is the need to secure and expand the enterprise of science itself. Building on previous results, new projects must continuously be forged. This is what defines the modus operandi of scientific research (Rouse 2005), supporting the incessant demands of the research enterprise by supplying new problems to work on, and new materials and institutional resources to work on them.

Heidegger's diagnostic is exemplified quite tellingly by contemporary life sciences research, notably by genomics in its multiple varieties and branches. Genomics is a particular way of securing and objectifying living entities, namely as bio-information, so that they can be sequenced and studied in a replicable manner. In the course of the twentieth century, Mendelian genetics (initially a handicraft, building on artisanal practices of plant cultivation) evolved into molecular and computational biology, interpreting life in terms of data, on the basis of the ontological conviction that life essentially is information (Venter 2013). Living beings are literally obliterated, replaced by letters (symbols, digital code), by terabytes of data litter. Genomics has evolved into a (technologically enhanced) global arena of planned research: a global research enterprise ("big science"). Automated sequencing machines enframe all living beings as carriers of information. This conveys a metaphysical claim, namely that all is one: all life is information. Indeed, the basic metaphysical claim grounding the life sciences in general and genomics in particular echoes Heraclitus' saying that "all

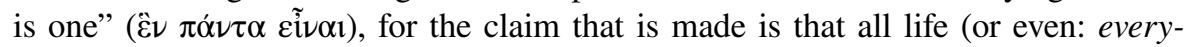
thing there is) is information (Heidegger1951/2000; GA7). This fundamental interpretation, this Begriff or Inbegriff ("encompassing claim": 2009; GA76: 77) is the conceptual ground which allows this type of research to unfold, relentlessly marginalising, eliminating or transforming all other ways of studying living nature (so that, in the genomics era, ecology becomes bio-prospecting). Even philosophical and ethical reflection becomes planned research, embedded in big science research programs: philosophers as specialists, addressing specific normative questions.

Nature is made calculable, is determined in terms of calculability. Heidegger himself uses elementary particle physics as his pet example (the smashing of atoms by big machines), but genomics has often been compared to "splitting" the atom: the equivalent of high energy physics in the realm of life sciences research (Zwart 2008: $375)$, where research outputs are generated, validated and communicated continuously. This technoscientific interpretation of all living beings, of everything ( $\pi \alpha \dot{\nu} \tau \alpha$ ) as information must be overcome by taking a step backwards. By recollecting Heraclitus's saying that all is one (Heidegger 1951/2000; GA7) we realise that the metaphysical claim at work in contemporary technoscience is one particular interpretation of what beings are, obfuscating other possible interpretations: other (less calculative and technological, more poetic) ways of standing out towards things we encounter. Indeed, the "relevance" of philosophy, as patient thinking, resides in a philosophical questioning of the metaphysical claim that is steering data-focussed life sciences research, thereby preparing the ground for a new beginning ("andere Anfang").

Genomics not only obliterates living beings (replacing them by digital code, assembled in data repositories) but also marginalises the work of the scientists themselves, relying increasingly on automation. The enterprising character of modern science 
affects its practitioners as well. On the side of the researcher (the subject-pole), genomics likewise entails erosion (Aushöhlung der forschenden Arbeit) of research work via automation (Heidegger 1938/1977; GA5: 97). Research requires constant activity, performativity and effectiveness rather than insight, although the actual work is outsourced to machines. Genomics is big science, ${ }^{6}$ representing the emergence of gigantism (das Riesenhafte) in life sciences research, even though, as Heidegger points out, the gigantic (big machinery) has the paradoxical tendency to focus on the increasingly small (1938/1977; GA5: 95), on elementary constituents of life (genes, nucleotides, amino acids, etc.). The gigantic makes nature computationable.

This does not mean that philosophers should retreat into mere erudition ("die Romantik des Gelehrtentums," 1938/1977; GA5: 85; see, 2009; GA 76: 113). They should be involved in this development, albeit in such a way that they are not completely seized by it. From a position of close proximity, philosophers may question, for instance, how quantification (i.e., the effort of making nature computational) has evolved into a very specific form of quantification, namely datafication, reflecting the metaphysical claim, already pointed out above, that everything is information. Genomics sequences, assembled in digital databases, exemplify what Heidegger refers to as "the endlessly extended emptiness of the purely quantitative" ("die endlos zerdehnte Leere des nur Quantitativen": 95). At the same time, however, the quantifiable is always surrounded by a remainder, something which remains unquantifiable, so that datafication (as a specific form of objectification) inevitably casts a non-representable shadow of unquantifiability (1938/1977; GA5: 95): a refuse which refuses computation.

We cannot negate the current computational trend by withdrawing into mere erudition of by trying to oppose it (protesting against datafication and the reduction of life to information) as this would merely confirm the marginalisation of reflection. Rather, the Heideggerian option would be to question the interpretation of being as information (and of truth as algorithmic validation) by taking a step backwards, preparing the ground for an exodus ("Auswanderung") out of this erosion of human experience (Heidegger 2009; GA76: 100), providing an alternative for the obliteration of nature at the object-pole of the knowledge-production process. How? By paying attention to the words we use, by stepping backwards, towards moments of commencement, acknowledging that genomics entails a particular interpretation of being and truth. It is not a mere technology in the instrumental sense ("applied research"), but a particular way of securing and understanding being (as information) and a particular way of securing and understanding truth (as validation and replication). Genomics is a global research enterprise, aiming to secure and enhance a particular way of proceeding. What makes research important is not the intrinsic significance of its discoveries, but the possibility of ensuring sufficient options for further research in terms of research programs, funding opportunities, lab facilities, and so on. Technoscience expands its domain of research by making entities extensively computable.

\footnotetext{
${ }^{6}$ From a European perspective, genomics may be seen as "Americanism" (1938/1977; GA5: 112). By this we actually mean, Heidegger argues, that biology became an enterprise (big science).
} 


\section{Concluding Reflection: Is a Technoscience-Philosophy Dialogue Possible?}

The later Heidegger seems pessimistic concerning the possibility of a genuine science-philosophy confrontation ("Auseinandersetzung"), not because they stand too far apart, but because they are so decidedly interlinked with each other, from the very beginning, that both seem unable, on their own initiative, to prepare the ground for such a conversation (Heidegger 2009; GA 76: 273). Moreover, there is no pathway leading from science to reflection. Therefore, the only option is to begin with a philosophical questioning of the way of being of the entities produced, studied and obliterated by technoscience, from a sideways perspective, going beyond the positive sciences themselves, posing questions they methodically exclude (van Mazijk 2019: 539). This is difficult, but not impossible, Heidegger maintains. Science has to remain informed about the way of being of the entities it studies, while metaphysics (having been assigned the question concerning the way of being of beings) must pay due attention to how these beings are actually made accessible and disclosed by science. Therefore, metaphysics and science both have an interest in addressing the question of the being of these beings together ("einträchtig": Heidegger 2009; GA 76: $276 \mathrm{f}$.). ${ }^{7}$ The being of beings manifests itself in multiple ways, as Aristoteles said

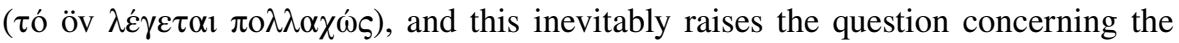
way of being of neo-things, brought to the fore by technoscience (Heidegger 2009; GA 76: 279). In this questioning practice resides philosophy's "relevance".

At the "subject-pole" of the knowledge production process, research becomes a technical endeavour, carried out by machines: an industrialised praxis, a form of labour, following procedures and protocols attuned to the technicity of technoscience. At the "object-pole," natural entities are likewise enframed in a technical manner. Living beings become molecular machines, guided by bio-molecular programs. As molecular biologist Max Delbrück (1971) argued, molecular biology echoes Aristotelean ideas, albeit in a technicised manner, for while molecules are the "mat-

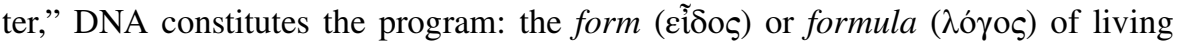
things (Zwart 2019). Genomics replaces the static (deterministic) logic of traditional genetics by an ontology of becoming (Rouse 2005). What is revealed and what is obfuscated in such an enframing of living beings, - which actually represents the completion of Western metaphysics (Heidegger 2009; GA 76: 294)? That is the type of question philosophy should ask. Not in an abstract manner, but by paying close attention to the language, practice and technicity of technoscience, so as to discern and question the guiding metaphysical claim at work in contemporary technoscience ("everything is information").

\footnotetext{
7 "Die Wissenschaft, die das Seiende erforscht, liegt daran, über das Sein des Seienden unterrichtet zu bleiben... Der Metaphysik andrerseits [ist] die Frage nach dem Sein des Seienden zugewiesen, wobei sie gebührend darauf achten wird, in welcher Gestalt ihr das Seiende durch die Wissenschaft zugänglich gemacht wird. Metaphysik und Wissenschaft finden sich somit in der Frage nach dem Sein des Seienden einträchtig zusammen" (2009; GA 76: 276f.).
} 
Open Access This article is licensed under a Creative Commons Attribution 4.0 International License, which permits use, sharing, adaptation, distribution and reproduction in any medium or format, as long as you give appropriate credit to the original author(s) and the source, provide a link to the Creative Commons licence, and indicate if changes were made. The images or other third party material in this article are included in the article's Creative Commons licence, unless indicated otherwise in a credit line to the material. If material is not included in the article's Creative Commons licence and your intended use is not permitted by statutory regulation or exceeds the permitted use, you will need to obtain permission directly from the copyright holder. To view a copy of this licence, visit http://creativecommons.org/licen ses/by/4.0/.

\section{References}

Babich, B. (2018). Between Heidegger and Adorno: Airplanes, radios, and Sloterdijks' atmoterrorism. Kronos: Philosophical Journal, 6(133), 158-301.

Blok, V. (2013). Towards the rehabilitation of the will in contemporary philosophy. Journal of the British Society for Phenomenology, 44(3), 286-301.

Blok, V. (2015). Heidegger and Derrida on the nature of questioning: Towards the rehabilitation of questioning in contemporary philosophy. Journal of the British Society for Phenomenology, 46(4), 307-322. https://doi.org/10.1080/00071773.2015.1052659.

Blok, V. (2020). Heidegger's concept of philosophical method: Innovating philosophy in the age of global warming. New York: Routledge.

Dahlstrom, D. (1994). Heidegger's method: Philosophical concepts as formal indications. The Review of Metaphysics, 47(4), 775-795.

Delbrück, M. (1971). Aristotle-totle-totle. In Jacques Monod \& Ernest Borek (Eds.), Of microbes and life (pp. 50-55). New York: Columbia University Press.

Fidalgo, A. (2009). Heidegger's cell phone - ubiquitous communication and existential distance. Revista MATRIZes, 3(1), 1-20.

Gadamer, H.-G. (1990). Wahrheit und Methode: Grundzüge einer philosophischen Hermeneutik. Tübingen: Mohr.

Glazebrook, T. (2000). Heidegger's philosophy of science. New York: Fordham University Press.

Glazebrook, T. (2012). Why read Heidegger on science?. Albany: SUNY Press.

Heidegger, M. (1920/1921/1995). Gesamtausgabe. II. Abteilung: Vorlesungen 1919-1944. Band 60: Phänomenologie des religiösen Lebens. Frankfurt am Main: Vittorio Klostermann (GA60).

Heidegger, M. (1927/1977). Gesamtausgabe. I. Abteilung: Veröffentlichte Schriften 1914-1970. Band 2: Sein und Zeit. Frankfurt am Main: Vittorio Klostermann (GA2).

Heidegger, M. (1927/1975). Gesamtausgabe. II. Abteilung: Vorlesungen 1923-1944. Band 24: Die Grundprobleme der Phänomenologie. Frankfurt am Main: Vittorio Klostermann (GA24).

Heidegger, M. (1935/1936/1977). "Der Ursprung des Kunstwerkes”. In: Gesamtausgabe. I. Abteilung: Veröffentlichte Schriften 1914-1970. Band 5: Holzwege, 1-74. Frankfurt am Main: Vittorio Klostermann (GA5).

Heidegger, M. (1938/1977). "Der Ursprung des Kunstwerkes”. In: Gesamtausgabe. I. Abteilung: Veröffentlichte Schriften 1914-1970. Band 5: Holzwege, 75-114. Frankfurt am Main: Vittorio Klostermann (GA5).

Heidegger, M. (1944/1945/1995). Gesamtausgabe. III. Abteilung: Unveröffentlichte Abhandlungen, Vorträge - Gedachtes. Band 77: Feldweg-Gespräche. Frankfurt am Main: Vittorio Klostermann (GA77).

Heidegger, M. (1946/1977). “Wozu Dichter?”. In: Gesamtausgabe. I. Abteilung: Veröffentlichte Schriften 1914-1970. Band 5: Holzwege, 269-320. Frankfurt am Main: Vittorio Klostermann (GA5).

Heidegger, M. (1950/2000). "Das Ding”. In: Gesamtausgabe. I. Abteilung: Veröffentlichte Schriften 19141970. Band 7: Vorträge und Aufsätze, 165-188. Frankfurt am Main: Vittorio Klostermann (GA7).

Heidegger, M. (1951/2000). "Logos (Heraklit, Fragment 50)”. In: Gesamtausgabe. I. Abteilung: Veröffentlichte Schriften 1914-1970. Band 7: Vorträge und Aufsätze, 211-234. Frankfurt am Main: Vittorio Klostermann (GA7).

Heidegger, M. (1953/2000). "Wissenschaft und Besinnung". In: Gesamtausgabe. I. Abteilung: Veröffentlichte Schriften 1914-1970. Band 7: Vorträge und Aufsätze, 37-66. Frankfurt am Main: Vittorio Klostermann (GA7).

Heidegger, M. (1954/2002). Gesamtausgabe. I. Abteilung: Veröffentlichte Schriften 1910-1976. Band 8: Was heißt denken? Frankfurt am Main: Vittorio Klostermann (GA8). 
Heidegger, M. (1955/2006). Was ist das - die Philosophie? In: Gesamtausgabe. I. Abteilung: Veröffentlichte Schriften 1910-1976. Band 11: Identität und Differenz, pp. 3-26. Frankfurt am Main: Vittorio Klostermann (GA11).

Heidegger, M. (1959/1985). Gesamtausgabe. I. Abteilung: Veröffentlichte Schriften 1910-1976. Band 12: Unterwegs zur Sprache. Frankfurt am Main: Vittorio Klostermann (GA12).

Heidegger, M. (1959/2017). Gesamtausgabe. IV. Abteilung: Hinweise und Aufzeichnungen. Band 89: Zollikoner Seminare. Frankfurt am Main: Vittorio Klostermann (GA89).

Heidegger, M. (2009). Gesamtausgabe. III. Abteilung: Unveröffentlichte Abhandlungen, Vorträge Gedachtes. Band 76: Leitgedanken zur Entstehung der Metaphysik, der neuzeitlichen Wissenschaft und modernen Technik. Frankfurt am Main: Vittorio Klostermann (GA76).

Hottois, G. (1984). Le signe et la technique: la philosophie à l'épreuve de la technique. Paris: Aubier.

Kastenhofer, K., \& Schwarz, A. (2011). Probing technoscience. Poiesis and praxis, 8(2-3), 61-65. https:// doi.org/10.1007/s10202-011-0103-0.

Knorr Cetina, K. (2002). Wissenskulturen: ein Vergleich naturwissenschaftlicher Wissensformen. Frankfurt: Suhrkamp.

Kockelmans, J. (1985). Heidegger and science. Washington, D.C.: Centre for Advanced Research in Phenomenology: University Press of America.

Latour, B., \& Woolgar, S. (1986). Laboratory life: The construction of scientific facts. Princeton: Princeton UP.

Lemmens, P. (2008). Gedreven door techniek: de menselijke conditie en de biotechnologische revolutie. Nijmegen: BoxPress/Radboud University.

Lynch, M. (1985). Art and artefact in laboratory science: Study of shop work and shop talk in a research laboratory. London: Routledge \& Kegan Paul.

Nugent, P. (2014). Rethinking Heidegger's framing of cybernetics: Toward a theory of phenomenal appreciation. IEEE Conference Norbert Wiener in the 21 st Century. https://doi.org/10.1109/norbert.2014.68939 16

Owens, W. (1987). Heidegger and the philosophy of language. Auslegung: A Journal of Philosophy, 14(1), 49-66.

Philipse, H. (1998). Heidegger's philosophy of being. A critical interpretation. Princeton: Princeton University Press.

Rader, K. (2004). Making mice: Standardizing animals for American biomedical research, 1900-1955. Princeton: Princeton University Press.

Rheinberger, H.-J. (2006). Epistemologie des Konkreten: Studien zur Geschichte der modernen Biologie. Frankfurt: Suhrkamp.

Rouse, J. (2005). Heidegger on science and naturalism. Division/Faculty Publications 36. https://wesscholar .wesleyan.edu/div1 facpubs/36

Stahl, L. M. (2018). Isolieren - Zerlegen - Stillstellen: Zum Verhältnis von Bios und Biologie am Beispiel mikroskopischer Bildgebung. München: Wilhelm Fink.

Streeter, R. (1997). Heidegger's formal indication: A question of method in being and time. Man and World, 30, 413-430.

Thomson, I. (1999). The end of onto-theology: Understanding Heidegger's turn, method, and politics (Thesis). San Diego: University of California.

van Mazijk, C. (2019). Heidegger and Husserl on the technological-scientific worldview. Human Studies, 42, 519-541. https://doi.org/10.1007/s10746-019-09526-2.

Venter, J. C. (2013). Life at the speed of light: From the double helix to the dawn of digital life. New York: Viking.

von Herrmann, F.-W. (1990). Weg und Methode: Zur hermeneutischen Phänomenologie des seinsgeschichtlichen Denkens. Frankfurt am Main: Klostermann.

Zwart, H. (2008). Understanding the human genome project: A biographical approach. New Genetics and Society, 27(4), 353-376.

Zwart, H. (2013). From playfulness and self-centredness via grand expectations to normalisation: A psychoanalytical rereading of the history of molecular genetics. Medicine, Health Care and Philosophy: A European Journal, 16(4), 775-788.

Zwart, H. (2016). The obliteration of life: Depersonalization and disembodiment in the terabyte era. New Genetics and Society, 35(1), 69-89. https://doi.org/10.1080/14636778.2016.1143770.

Zwart, H. (2017). The oblique perspective: Philosophical diagnostics of contemporary life sciences research. Life Sciences, Society and Policy, 13, 4. https://doi.org/10.1186/s40504-017-0047-9. 
Zwart, H. (2019). What is mimicked by biomimicry? Synthetic cells as exemplifications of the three-fold biomimicry paradox. Environmental Values, 28(5), 527-549. https://doi.org/10.3197/096327119X15579 936382356.

Zwart, (2020). Iconoclasm and Imagination: Gaston Bachelard's philosophy of technoscience. Human Studies, 43, 61-87. https://doi.org/10.1007/s10746-019-09529-z.

Zwier, J., \& Blok, V. (2019). Seeing through the fumes: Technology and asymmetry in the Anthropocene. Human Studies, 42(4), 621-646.

Publisher's Note Springer Nature remains neutral with regard to jurisdictional claims in published maps and institutional affiliations. 